\title{
Correction: Cbl-b inhibits P-gp transporter function by preventing its translocation into caveolae in multiple drug- resistant gastric and breast cancers
}

\section{Ye Zhang ${ }^{1}$, Xiujuan Qu ${ }^{1}$, Yuee Teng ${ }^{1}$, Zhi Li ${ }^{1}$, Ling $X u^{1}$, Jing Liu ${ }^{1}$, Yanju Ma ${ }^{1}$, Yibo Fan $^{1}$, Ce Li ${ }^{1}$, Shizhou Liu ${ }^{1}$, Zhenning Wang ${ }^{2}$, Xuejun $\mathrm{Hu}^{3}$, Jingdong Zhang ${ }^{1}$ and Yunpeng Liu ${ }^{1}$}

\footnotetext{
${ }^{1}$ Department of Medical Oncology, the First Hospital of China Medical University, Shenyang 110001, China

2 Department of Surgical Oncology and General Surgery, the First Hospital of China Medical University, Shenyang 110001, China

${ }^{3}$ Department of Medical Respiratory, the First Hospital of China Medical University, Shenyang 110001, China
}

Published: August 03, 2021

Copyright: () 2021 Zhang et al. This is an open access article distributed under the terms of the Creative Commons Attribution License (CC BY 3.0), which permits unrestricted use, distribution, and reproduction in any medium, provided the original author and source are credited.

This article has been corrected: Due to errors during figure assembly, the fluorescence images in Figure 3E are accidental duplicates of those in Figures 1D and 2D. The corrected Figure 3, as well as an updated Figure 2 showing a correctly paired "control" and "+ DOX", are shown below. In addition, the title of Table 1 should be "breast cancer", not "gastric cancer." All revisions presented were obtained with the original data. The authors declare that these corrections do not change the results or conclusions of this paper.

Original article: Oncotarget. 2015; 6:6737-6748. https://doi.org/10.18632/oncotarget.3253 
A

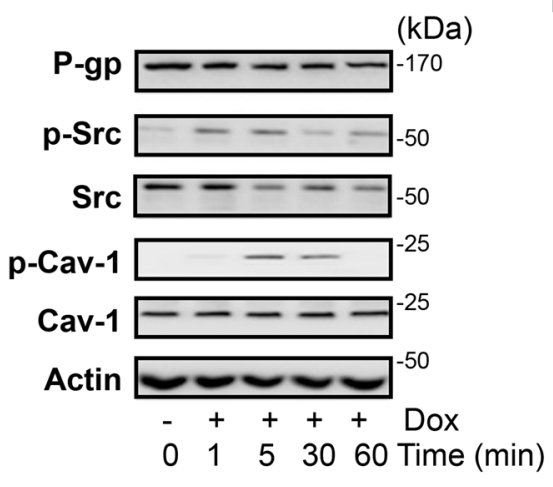

B

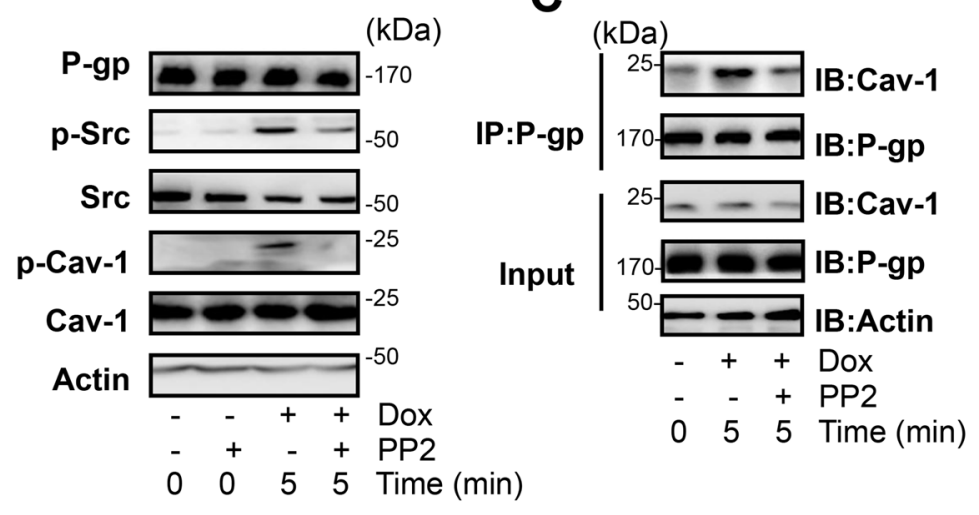

D

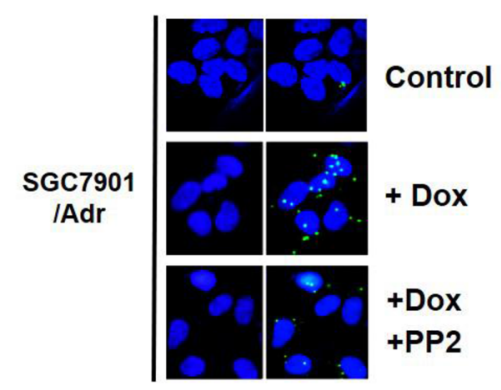

E

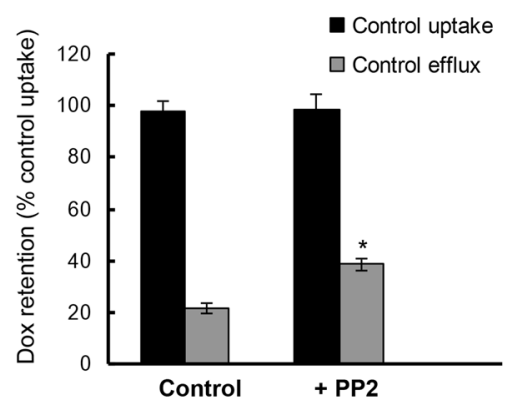

Figure 2: c-Src dependent Cav-1 phosphorylation promoted the translocation of P-gp into caveolae. (A) SGC7901/Adr cells were treated with or without $20 \mu \mathrm{g} / \mathrm{ml}$ Dox for 1, 5, 30, $60 \mathrm{~min}$ and the expression of P-gp, p-Src, Src, p-Cav-1, Cav-1 and Actin was detected by western blotting. (B) Cells were incubated with the Src inhibitor PP2 (10 $\mu \mathrm{mol} / \mathrm{l})$ for $2 \mathrm{~h}$, treated with $20 \mu \mathrm{g} / \mathrm{ml} \mathrm{Dox}$ for $5 \mathrm{~min}$, and the expression of P-gp, p-Src, Src, p-Cav-1, Cav-1 and Actin was detected by western blotting. (C) SGC7901/Adr cells were pretreated with $10 \mu \mathrm{mol} / 1 \mathrm{PP} 2$ for $2 \mathrm{~h}$ followed by Dox treatment, and P-gp was immunoprecipitated and Cav-1 was analyzed western blotting. (D) In situ PLA in SGC7901/Adr cells pretreated with or without $10 \mu \mathrm{mol} / 1 \mathrm{PP} 2$ for $2 \mathrm{~h}$, and then incubated with $20 \mu \mathrm{g} / \mathrm{ml} \mathrm{Dox}$ for $5 \mathrm{~min}$. Primary mouse and rabbit antibodies against P-gp and Cav-1 were combined with secondary PLA probes. (E) SGC7901/Adr cells were pretreated with $10 \mu \mathrm{mol} / 1 \mathrm{PP} 2$ for $2 \mathrm{~h}$, followed by $20 \mu \mathrm{g} / \mathrm{ml}$ Dox and assessment of R-123 uptake and efflux. 


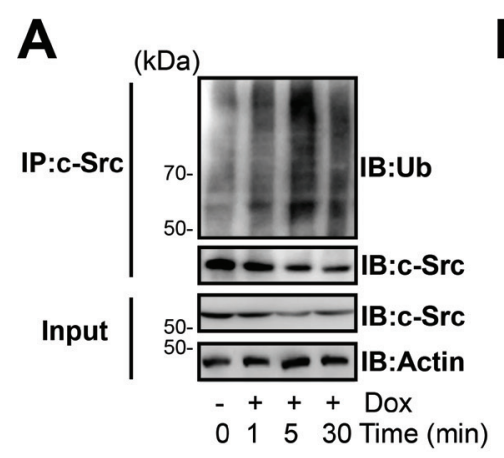

B
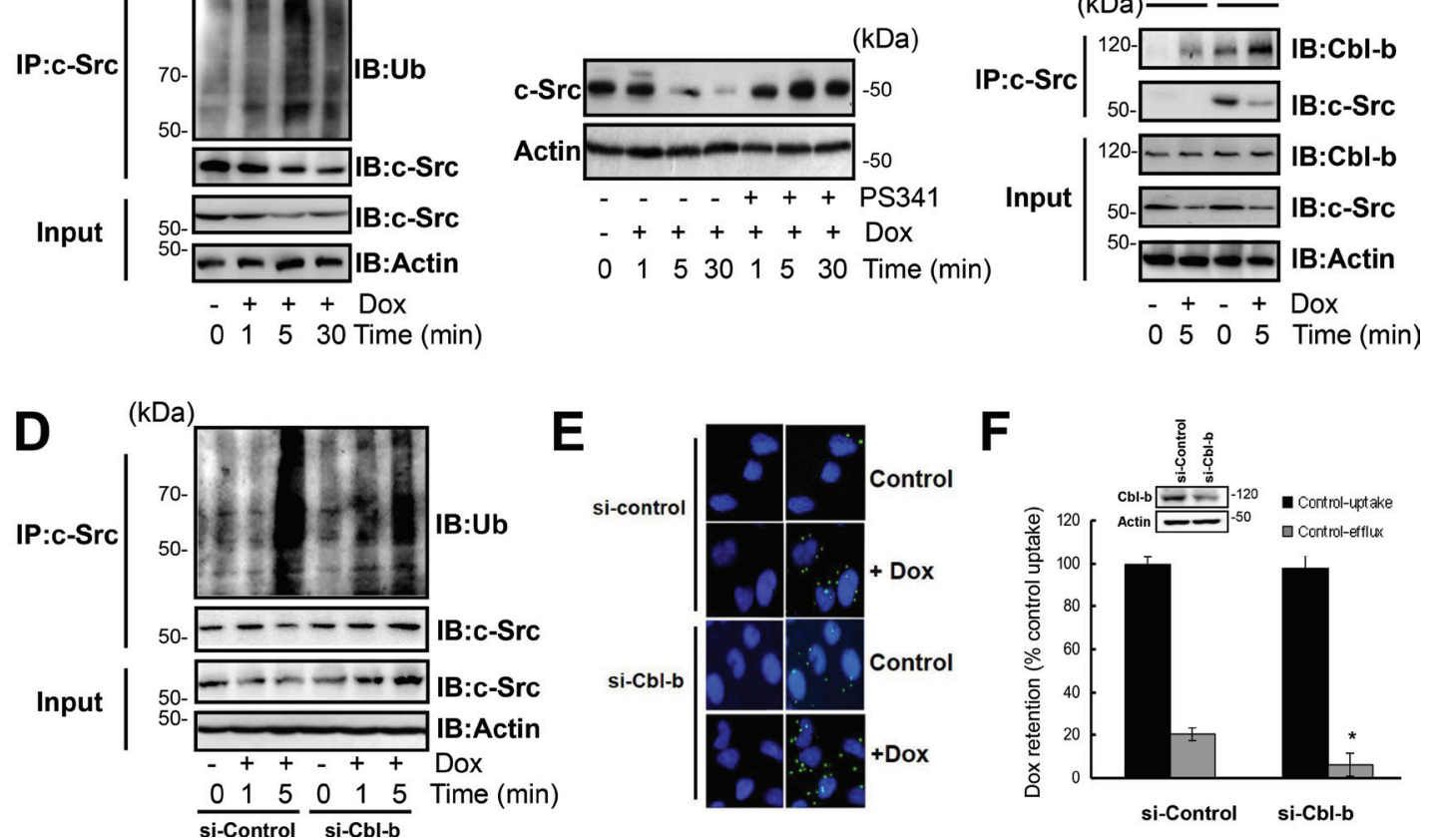

Figure 3: Cbl-b inhibited the translocation of P-gp into caveolae by inducing the ubiquitination and degradation of c-Src. (A) SGC7901/Adr cells were exposed to $20 \mu \mathrm{g} / \mathrm{ml}$ Dox for 1, 5, $30 \mathrm{~min}, \mathrm{c}-\mathrm{Src}$ was immunoprecipitated and ubiquitin was analyzed by western blotting. (B) SGC7901/Adr cells were incubated with PS341 $(5 \mathrm{nmol} / \mathrm{l})$ for $12 \mathrm{~h}$, then treated with $20 \mu \mathrm{g} / \mathrm{ml}$ Dox for $5 \mathrm{~min}$, and the expression of the Src protein was analyzed by western blotting. (C) SGC7901/Adr cells were treated with or without $20 \mu \mathrm{g} / \mathrm{ml}$ Dox for 5, c-Src was immunoprecipitated and Cbl-b was analyzed by western blotting. (D) SGC7901/Adr cells were transiently transfected with Cbl-b siRNA (si-Cbl-b) for $48 \mathrm{~h}$, followed by $20 \mu \mathrm{g} / \mathrm{ml}$ Dox for 1 or $5 \mathrm{~min}$, c-Src was immunoprecipitated and ubiquitin was analyzed by western blotting. (E) SGC7901/Adr cells were transiently transfected with Cbl-b siRNA (si-Cbl-b) for $48 \mathrm{~h}$ and analyzed by PLA after incubation with $20 \mu \mathrm{g} / \mathrm{ml}$ Dox for $5 \mathrm{~min}$. Primary mouse and rabbit antibodies against the P-gp and Cav-1 were combined with secondary PLA probes. (F) SGC7901/Adr cells were transiently transfected with Cbl-b siRNA (si-Cbl-b) for $48 \mathrm{~h}$, followed by $20 \mu \mathrm{g} / \mathrm{ml}$ Dox and analysis of Dox uptake and efflux. 
Table 1: Relationship between the expression of Cbl-b and clinico-pathological characteristics of P-gp-positive breast cancer patients

\begin{tabular}{|c|c|c|c|c|c|}
\hline \multirow{2}{*}{ Clinico-pathological characteristics } & & \multirow{2}{*}{ Number } & \multicolumn{2}{|c|}{ Cbl-b expression } & \multirow{2}{*}{$p$ value } \\
\hline & & & Negative & Positive & \\
\hline \multicolumn{6}{|l|}{ Age (years) } \\
\hline & $\leq 35$ & 7 & 5 & 2 & \\
\hline & $>35$ & 114 & 43 & 71 & 0.112 \\
\hline \multicolumn{6}{|l|}{ Tumour size $(\mathrm{cm})$} \\
\hline & $\leq 2$ & 19 & 9 & 10 & \\
\hline & $>2$ & 102 & 39 & 63 & 0.455 \\
\hline \multicolumn{6}{|l|}{$\mathrm{pN}$ stage } \\
\hline & 0 & 58 & 19 & 39 & \\
\hline & $1-3$ & 63 & 29 & 34 & 0.136 \\
\hline \multicolumn{6}{|l|}{ Histology grade } \\
\hline & $1+2$ & 87 & 33 & 54 & \\
\hline & 3 & 34 & 15 & 19 & 0.532 \\
\hline \multicolumn{6}{|l|}{ ER/PR status $§$} \\
\hline & Negative & 59 & 19 & 40 & \\
\hline & Positive & 62 & 29 & 33 & 0.101 \\
\hline \multicolumn{6}{|l|}{ HER2 status ${ }^{\pi}$} \\
\hline & Negative & 39 & 22 & 17 & \\
\hline & Positive & 82 & 26 & 56 & $0.009^{1}$ \\
\hline
\end{tabular}

${ }^{1}$ Two-sided $p$ value; values shown in bold are statistically significant.

${ }^{\S}$ ER/PR status: oestrogen receptor or progesterone receptor status by immunohistochemistry (IHC); negative: ER and PR double negative; positive: ER or PR positive.

"HER2 status: HER2-positive status is IHC 3+ or fluorescence in situ hybridisation (FISH) positive; HER2-negative status is IHC $0,1+$ or FISH negative.

HER2, Human epidermal growth factor receptor 2. 